Volume: 1 | Number 1 | pp. 45 - 59

ISSN: 2633-352X (Print) | ISSN: 2633-3538 (Online) journals.tplondon.com/ijor

First Submitted: 15 July 2020 Accepted: 1 November 2020

DOI: https://doi.org/10.33182/ijor.v1i1.1089

\title{
Is Right-wing Populism a Phenomenon of Religious Dissent? The Cases of the Lega and the Rassemblement National
}

\author{
Luca Ozzano ${ }^{1}$ and Fabio Bolzonar ${ }^{2}$
}

\begin{abstract}
The current global political landscape is increasingly marked by the growth of right-wing populist parties. Although this party family has been the subject of a bourgeoning scholarship, the role played by religion in shaping its ideology is still an under-researched topic. Drawing on the qualitative context analysis of a large database of newspaper articles, electoral manifestos, and parties' documents, this article studies the influence of religion on the political platforms of the Lega Nord (LN - recently rebranded just Lega) in Italy and the Front National (recently renamed Rassemblement National - RN) in France since the early 1980s. Our aim is twofold. Firstly, we would like to describe the role of religious values in the different political phases of the life of these parties. Secondly, we wish to assess whether and to which extent the appropriation of religion by these parties can be considered a phenomenon of religious dissent. Our analysis focuses on LGBT+ rights, a policy field that tends to bear the imprint of religion norms. Past studies have noted that right-wing populist parties support not only a nativist idea of citizenship, which prompts anti-immigrants and anti-Islamic stances, but also conservative interpretations of Christian values in terms of family issues and gender roles. In the last three decades, European right-wing populist parties have partly revised their positions on these issues. While some of them, like the Lega, have strengthened or made only marginal changes to their religiously-inspired moral conservatism, others, like the RN, have shown new openings on gender equality and LGBT+ rights.
\end{abstract}

Keywords: Right-wing populism; religious dissent; Catholicism; LGBT+ rights; France; Italy.

\section{Introduction: Populism, Religion and LGBT+ issues}

In the twenty-first century, the political landscape of several countries has undergone a remarkable transformation as a consequence of the rise of populist parties. Although populism has become an increasingly popular concept in contemporary politics, it is a contested and elusive term that has been often used to describe political phenomena that may appear mutually exclusive (Müller 2016, 7). Heads of the state like Donald Trump and Hugo Chavez, political parties like SYRIZA in Greece and Law and Justice in Poland, and anti-establishment movements that are difficult to locate on the right-left scale, like the Five Star Movement in Italy, all have been considered populist. In this article, we adopt an ideational approach to populism, according to which populism is a set of ideas with a limited programmatic scope that depicts societies as divided between the "pure people" and the "corrupted elites". Starting from this Manichean and moralistic distinction, populist leaders present themselves as the better defenders of the general will and claim 'that politics is about respecting popular sovereignty at any cost' (Mudde and Rovira Kaltwasser 2018, 1669). The anti-elite side of populism, however, is only its 'vertical' dimension, which is shared by right-wing, left-wing and officially non-partisan populist movements and parties. What specifically singles out right-wing

\footnotetext{
${ }^{1}$ Prof. Luca Ozzano, University of Turin, Italy. E-mail: luca.ozzano@unito.it

${ }^{2}$ Dr Fabio Bolzonar, Université Libre de Bruxelles, Belgium. E-mail: fabio.bolzonar@cantab.net
} 
populism is its 'horizontal' dimension, that is, the opposition to others who are perceived - or at least portrayed - as threatening towards the local/national community, its values, and its wellbeing.

Besides a clearer operationalization of their concepts, scholars who have been studying populism would foster a better accumulation of knowledge if they cross-fertilize their studies with other fields to explore new avenues of research (Mudde and Rovira Kaltwasser 2018, 1686). Some recent works on the religious side of populism, arguably one of the most understudied areas in the bourgeoning scholarship on populism (DeHanas and Shterin 2018) seem to go in this direction (Haynes 2019; Ozzano 2019; Arato and Cohen 2017; Brubaker 2017; Marzouki and McDonnell 2016). Arato and Cohen have pointed out how the politicization of religion by right-wing populist movements undermines the open, pluralistic, and inclusive principles that characterize the civil society in democratic countries. In other words, populists use religion to further their political agenda (Arato and Cohen 2017, 283), which systematically aims to suppress civil society (Müller 2016, 4). Populist parties' invocation of religion is often linked with the central tenets of the thin-centred ideology of these parties (Mudde, 2004) notably the "pure people" and the "corrupted elites". Marzouki, McDonnell, and Roy have claimed that right-wing populist parties hijack religion to define the people, conceived in nativist and exclusionary terms, and to distinguish the people from the others, particularly Muslim migrants, considered a threat for the national community (Marzouki et al. 2016). In doing that, for far-right populist movements, religion is nothing more than an identity marker rather than a matter of belief, in the context of a battle against "two groups of "enemies of the people": the elites who disregard the importance of the people's religious heritage, and the "others" who seek to impose their religious values and laws upon the native population' (Marzouki and McDonnell 2016: 2). The appropriation of religion by right-wing populist parties varies in different national contexts. The state-religion arrangements, the prevailing idea of nationalism in a given country, and the ideological roots of the various populist movements influence the populist religiosity (Scrinzi 2017) that ranges from 'Christianist secularism', where a republican idea of citizenship prevails, to civilizational discourses, to political claims deeply imbued of devotional religiosity (Haynes 2019; Ozzano 2019; Arato and Cohen 2017; Brubaker 2017; Marzouki and McDonnell 2016). However, the public display of religious tropes by populist leaders to sustain their political agenda have created strains with religious authorities, particularly with the Vatican: Pope Francis, for example, has expressed strong condemnation of the forms of sovereignism of populism. ${ }^{3}$ In his latest encyclical titled Fratelli Tutti (All Brothers) issued in October 2020, the Pope has even stigmatized 'those who appear to feel encouraged or at least permitted by their faith to support varieties of narrow and violent nationalism, xenophobia and contempt, and even the mistreatment of those who are different.' (Francis 2020, Paragraph 86). However, the positions of Francis are not unanimously shared by the Catholic hierarchy and the community of believers. The internal pluralism that has always characterized Catholicism along all its history has also come out about populism. Some senior prelates, like Cardinal Raymond Leo Burke and Cardinal Carlo Maria Viganó, who are close to the Trump administration, have raised strong criticisms against the Pope. This mounting opposition within the Church has also triggered growing polarization among the community of believers itself. In this case, the main cleavage is often between practising believers, who recognize religious leaders as the ultimate source of authority, and occasionally practicing and non-practising believers, who prioritize political ideologies and an identity-driven idea of Catholicism (Ozzano 2019, 2016).

${ }^{3}$ La Stampa, August 9, 2019. 
The complex and multi-faceted questions that loom large in the relationship between right-wing populism and religion would suggest giving a closer look to them to study whether and to what extent the populists' appropriation of religion can be considered a case of religious dissent, thereby populist leaders re-elaborate and re-interpret religious tenets to provide an alternative understanding of religion in contrast with the official positions of religious authorities.

A promising perspective that allows highlighting the religious side of populism, and particularly the phenomena of religious dissent it can be linked to, is provided by gender and sexuality, which offer the most challenging dimensions in a consideration of the contemporary relevance of religion. (Vaggione 2005, 233) and the object of an ongoing revision of the political platforms of several rightwing populist parties (Brubaker 2017; Scrinzi 2017; De Lange and Mügge 2015). Right-wing populism has traditionally rejected gender diversity policies (Verloo 2018). This attitude is often linked to traditionalist religious doctrines sustained by conservative Catholic groups and the Catholic Church (Kuhar and Paternotte 2017). However, gender and sexuality issues are difficult subjects for populists that consider them as peripheral concepts that have to be adapted in accordance with the prevailing cultural values in a given society (Mudde and Rovira Kaltwasser 2015). Accordingly, when we put religion in relation to gender issues, the positions of right-wing populist movements reveal a great diversity that varies from an exclusionary vision of society based on conservative religious values rejecting gender equality, to platforms seemingly open to 'philosemitism, gender equality, and support for gay rights', although mainly in anti-Islamic perspective (Brubaker 2017).

This paper casts light on the relations between populism and religion, through a study of the role of religious values and tropes in sustaining the positions of the Lega Nord (Northern League - LN, later renamed just Lega) in Italy and the Front National (FN, recently rebranded Rassemblement National - RN) in France on LGBT+ rights. ${ }^{4}$ We chose these two parties, which belong to the European right-wing populist party family (Ignazi 2006), because their ideological developments on religion and LGBT + issues have followed paradigmatically different trajectories in the last three decades. While the Lega has maintained or only marginally changed its moral conservatism that it justified on the ground of a traditionalist understanding of Catholic anthropological values, the $\mathrm{RN}$ has left aside its early religious conservatism to adopt more permissive positions on LGBT+ issues.

Drawing on qualitative context analysis of political discourses, electoral manifestos, policy papers, and a large database of newspaper articles, we first argue that the different positions among Italian and French right-wing populists about LGBT + issues are partly a consequence of different traditions of religion/politics arrangements, nationalism, and citizenship in the two countries. Moreover, in accordance with the main theme of the special issue of which this paper is part, we conclude that the appropriation of religion by the League and the $\mathrm{RN}$ is not primarily a phenomenon of religious dissent, and mostly pertains to the sphere of symbolic and electoral politics, and to the identification of the Church hierarchies as part of the "elite" opposed to the "pure people", although it is also the expression of cultural roots ill at ease with a multicultural understanding of the world, and, more specifically, with post-conciliary Catholicism. As described below, in the early years of both parties this orientation made their leaders to sympathize with anti-conciliary movements such as Msg. Lefebvre's (and, in the case of the LN, also with neo-Paganism). In recent years, with a leadership change in both parties, the $\mathrm{FN} / \mathrm{RN}$ has experienced a secularist turn, with a downplay of religious identity in favour of a secular (although identity-driven) nationalism; on the other hand, Salvini's Lega

\footnotetext{
${ }^{4}$ Although the paper is the result of a common effort of the authors, the analysis of the Italian case has been elaborated and written by Luca Ozzano, and that of the French case by Fabio Bolzonar.
} 
seems instead to have opted for an ostentatiously devotional and identity-based Catholicism, openly at odds with pope Francis's view of the Church. It is too soon to say if this development - started with the campaign for the 2018 elections - will develop into a fully-fledged phenomenon of religious dissent. However, the controversies it is creating within the Catholic community itself seems to show that it caters on real cleavages at work within the Church and the community of believers.

This paper proceeds as follows: following this introduction, the next two empirical sections explore the evolution of the positions of the Lega and the RN on LGBT+ issues, to understand which kind of religion or religiosity they can be inscribed to. The concluding remarks compare our two cases, and try to answer our research questions, relating our conclusions to the wider literature on rightwing populism, religion and gender in contemporary Europe, and religious dissent.

\section{The Case of the Lega in Italy}

\section{Introduction}

Although LGBT+ organizations, and outspoken homosexual intellectuals - such as Pierpaolo Pasolini - had been active in Italy since the early 1970s, homosexuality has for a long time been a taboo in the Italian public discourse. This was a consequence of several factors: particularly, the predominantly Catholic culture of the country, and the hegemony of the Democrazia Cristiana party in the Italian governments until the early 1990s (Garelli, Guizzardi, and Pace 2003; Diotallevi 2002); and the predominance of a tradition of partial tolerance of homosexual behaviours only insofar they remained purely private, without any public display: a feature of Fascism which the DC party had later mostly upheld (Rossi Barilli 1999). It was only in the 2000s that the issue really came to the fore in the national media, both thanks to an increased visibility of the LGBT+ movements, and to the election of LGBT+ activists as MPs. All this made possible the inclusion of the legalization of samesex unions in the platform of the centre-left coalition for the 2006 and the 2013 elections. ${ }^{5}$ In both cases, the very narrow victory of the coalition, and the fact that it included centrist Catholics strongly influenced by the Church (Moscati 2010) did not make possible the approval of a law (Ozzano and Giorgi 2016). Same-sex unions were finally legalized only in 2016, also thanks to the lower profile adopted on this issue by the Catholic Church (Ozzano 2020). However, other LGBT+-related pieces of legislation, such as a law specifically punishing homo- and trans-phobia, haven't been approved yet, mainly because of Catholic opposition (Garbagnoli and Prearo 2017; Ozzano and Giorgi 2016). ${ }^{6}$

\section{The Lega (Nord) Party, Religion, and LGBT+ Issues}

The Lega Nord party (insofar LN) was created in 1991 as the federation of several regionalist parties based in northern Italy. At the time it was mainly focused on the centre vs. periphery cleavage, with a strong opposition against both Rome's elites and immigration from Southern Italy. At the time, the party did not refrain to rely on neo-Pagan rituals and anticlerical speeches to try to build a distinctive northern Italian identity and to mark its distance from Rome. Notwithstanding, a very committed conservative Catholic faction, the 'Catholic Padans' already existed within the party, and the party did not refrain even from showing sympathy for pre-conciliary Catholic traditionalism and the Lefebvrian congregation. These orientations occasionally came to the fore, for example in the debate

\footnotetext{
${ }^{5}$ In the other Italian elections of the 21 st century, including 2018, LGBT+ issues have not played a significant role in the campaign.

${ }^{6}$ At the time of finalizing this article, in October 2020, a new draft bill on the subject, proposed by Alessandro Zan (Democratic Party), is being discussed by the Parliament.
} 
about the inauguration of the 'Great mosque' of Rome in 1995 (McDonnell 2016; Guolo 2011). This event prefigured some LN positions of the 2000s and 2010s, when the party seemed at times ill at ease with the post-Council Catholic Church (mainly in terms of support of multiculturalism and religious dialogue), especially after the rise of Pope Francis to the Holy See.

The first great emergence of LGBT+ issues in the Italian public debate happened as a consequence of the World Pride parade held in Rome in July 2000. It is not by chance, therefore, that we can find the first clear LN's reference to LGBT+ issues in a September 2000 discourse of the party leader, Umberto Bossi:

The strong powers support the homosexual family. They can't have children, so values are dismantled. And the left, the red Nazis, they don't like the traditional family. Allied to the bankers and the strong powers, they dream of a utopia. Of a single moral code, a single race, a single size, the artificial uterus. ${ }^{7}$

Bossi also explicitly defined the Pride event as "a wakeup call", while reiterating the idea that, although he invited people to oppose the "homosexual lobbies", homosexual behaviour had not to be condemned insofar it remained "under the blankets" (a position which someway recalled the attitude of the Fascist regime and the DC party throughout most of the 20th century) (Rossi Barilli 1999). As a consequence, Bossi defined marriage equality as "a laughable issue". 8 This statement is striking because it not only sketched very clearly the positions adopted by the party on LGBT+ issues in the following years; but it also prefigured other right-wing populist tropes, such as the defence of the "traditional family", and the opposition to the leftist elites, Europeanization, and economic globalization.

This attitude, which combined the rejection of the idea that the LGBT+ community deserved any right - and, indeed, any acknowledgement outside the idea of "homosexual lobby" - and the use of deliberately politically incorrect language and puns, was very evident in the following years. For example, during the debate about the legalization of same-sex marriage in Spain, La Padania, the official newspaper of the party, used titles such as "La favola di finocchio" (The fable of faggot). ${ }^{9}$ It is therefore not a surprise that, when the Italian parliament, after the centre-left victory in the 2006 elections, started to discuss projects of legalization of same-sex partnerships (first according to the model of the French 'PACS', and later, as a consequence of the Catholic opposition, according to the model of the German 'registered partnerships') the LN representatives aligned with the Catholic world and were indeed among the staunchest opponents of any draft bill on marriage equality. In the same way, the party opposed several draft bills on the punishment of homophobic crimes and sexual discrimination against LGBT+ people that were put forward by LGBT+ activists elected as MPs in the centre-left parties. This opposition to LGBT+ rights was often explicitly framed in religious terms by the party representatives: Calderoli, for example, justified his position by saying that "the good God made us with different qualities: man and woman". ${ }^{10}$ Most LN statements on the issue seemed indeed linked to a patriarchal and machismo-inspired worldview of the mainly male party leadership, rather than to theological concerns and religious dissent. Nevertheless, the LN representatives did

\footnotetext{
${ }^{7}$ La Repubblica, September 18, 2000.

${ }^{8}$ Ibid.

${ }^{9}$ La Padania, April 25, 2005.

${ }^{10}$ La Repubblica, 4, September 2005.
} 


\section{The Cases of the Lega and the Rassemblement National}

not refrain from harshly criticizing the positions of the Catholic Church and its representatives, whenever they clashed with the party's platform, especially in relation to immigration, multiculturalism, religious pluralism, and relations with Islam (Ozzano 2016; Ozzano and Giorgi 2016; Guolo 2011).

These policy and discursive choices were part of a larger strategy of the party that, after displaying ambiguous attitudes towards religion and the Catholic Church until the 1990s, now poised as the defender of 'traditional values' and the 'traditional family'. As a consequence, the LN engaged not only against LGBT+ rights, but also against medically assisted procreation and stem cell research, in favor of the crucifix in public classrooms, and in support of the inclusion of a reference to 'the Christian roots' of Europe in the preamble to the draft EU constitution (Ozzano and Giorgi 2016). Its main focus, however, became the struggle against Islamic immigration, and the public signs of its presence in Europe, particularly in terms of places of worship and dress code: a target which however in the LN discourse was not rarely merged with LGBT+ issues (as already shown in the above quoted Bossi speech) and even abortion rights to polemicize against EU and national elites (allegedly willing to lower the birth rate in European countries and to favour Muslim immigration, in order to deconstruct the family-based 'traditional society') (Ozzano 2016).

This kind of discourse became more explicit in the 2010s, when many opponents of the recognition of LGBT+ rights, also in the centrist Catholic field, started to frame this opposition in the context of an alleged 'gender conspiracy' - promoted by the left, the supranational elites and the 'homosexual lobbies' - in order to mainstream the idea that gender was not a biological fact, but a free choice of the individual. This idea also inspired the mobilization of the sentinelle in piedi (standing sentinels), a grassroots movement composed mainly by conservative Catholic and right-wing people who silently stood in city squares reading a book to signify their opposition to the 'gender ideology' (Garbagnoli 2017; Garbagnoli and Prearo 2017).

The main target of the anti-gender mobilization in the mid-2010s was once again the idea of legalizing same-sex unions, since the centre-left coalition had included in its programme for the 2013 election a law on the issue. This time, the coalition also included a party, Left, Ecology and Freedom (Sinistra Ecologia e Libertà - SEL) which was led by an outspoken homosexual and pro-LGBT+ rights activist, Nichi Vendola, who during the campaign did not refrain from stressing the issue, also at the personal level, in reference to his desire to marry his partner. ${ }^{11}$ Moreover, Pope Francis's Vatican seemed much less focused on sexuality and morality issues than it was in the previous decade, and the Church representatives now often signified their opposition in terms of priorities and opportunities in times of economic crisis, rather than 'natural law' and 'common good' as they had done in the 2000s (Ozzano and Giorgi 2016; Ozzano 2015). This paved the way for an even harsher divide between the positions of the party and the Vatican, which however mostly centered around immigration and multiculturalism-related issues.

In the meantime, the $\mathrm{LN}$ had undergone a major change, with the rise to power within the party after a period of electoral crisis and scandals - of a new leader, Matteo Salvini. This latter completed the transformation of the LN (hereby referred to simply as 'Lega') from a regionalist into a fullyfledged right-wing nationalist and populist party with a main focus on immigration (not necessarily framed in religious terms) and security (Ozzano 2019; Passarelli and Tuorto 2018): a change also shown by the choice to drop the word 'nord' (north) from the LN symbol. This new political phase

${ }^{11}$ Il Fatto Quotidiano and Pubblico, 5 September 2012. 
also brought a new approach style in relation to LGBT+ issues. On the one hand, the Lega stood out as the staunchest opponent of the draft bill on same-sex unions: a point well shown not only by the parliamentary and public debate, but also by the fact that, at the moment of the final discussion in the Senate, about 5,000 of the 6,000 total amendments to the text on the parliamentary floor had been proposed by Lega representatives. ${ }^{12}$ Moreover, the party strongly supported a Family Day event that had been organized - with the purpose to show the alleged opposition of the civil society to the bill - by conservative sectors of Catholic associationism and right-wing groups (while the Vatican and the main Catholic movements had mainly avoided to officially endorsing the event, although in some cases commending it) (Prearo 2017): which was another demonstration that a growing divide between populist-inspired and centrist/progressive positions was also developing at the civil society, not only political, level, and among the Italian Catholic community itself.

On the other hand, in terms of principles, Salvini aligned with the new dominant discourse of relative openness towards the recognition of some basic LGBT+ rights (in the 2010s even some high-level representatives of the Catholic Church expressed their approval for the recognition of some individual rights for homosexual people). In May 2015 (still far away from the moment of the actual discussion of the law in parliament) he signalled thus a limited openness towards the recognition of some LGBT+ rights, provided the peculiarity of marriage between man and woman was defended. ${ }^{13}$ This evolution went hand-in-hand with a new linguistic approach, which refrained from adopting an exaggerated politically incorrect language, as happened in the 2000s. Indeed, while carrying on the battle in parliament, the Lega representatives did not stand out for their interventions in the public debate, mostly limiting themselves to references to the defence of the family, traditional marriage, and children (in relation to the possibility of adoption for same-sex couples).

This duality also emerged in the following years, when, after the 2018 elections, the party managed to form a coalition government with the Five Star Movement and Salvini became Vice-Prime Minister and Minister of the Interior. In this case, the Lega was crucial for the decision to create a Ministry of Family and Disability and to appoint for that task Lorenzo Fontana. This latter, a former LN ViceSecretary and European Parliament MP, had never hidden his ultra-conservative Catholic and rightwing identity, and defined himself "a crusader", as an opponent of abortion, euthanasia, LGBT+ rights and the 'gender ideology': issues which, in his view, cooperated with mass immigration in promoting the "erasure of our community and our traditions [...] the erasure of our people" (Oggiano 2018).

The LN also expressed its support for the defence of the 'traditional family' by bestowing the government's endorsement to the very controversial World Congress of Families, held in Verona (home of Fontana) in March 2019. Three Lega ministers (Salvini, Fontana and the Minister of Education Bussetti) also officially participated and spoke at the event. During electoral rallies and political debates, Salvini also started to openly use religious symbols, such as the Gospel and the crucifix, and to use religious references and tones (a behaviour stigmatized not only by other politicians, but also by the Vatican itself). At the same time, however, since the creation of the government, Salvini made very clear - when a major discussion erupted on the national media about

\footnotetext{
${ }^{12}$ La Repubblica, 22 January, 2016; Il Manifesto, 23 January, 2016.

${ }^{13}$ La Repubblica, 23 May, 2015; Il Giornale, 23 May, 2015.
} 
Fontana's positions - that he did not want to put into question the laws on abortion and same-sex unions, since these issues were not in the government platform. ${ }^{14}$

To sum up, the party has started in the 1980s and 1990s from a political ideology marked by patriarchalism and a familiarity with a pre-conciliar traditionalist vision of Christianity which did not disdain criticism towards the Vatican, not rarely portrayed as part of the elites. In the 21 st century, with the party's transformation into a nationalist right-wing populist party, this orientation has translated into positions strongly hostile towards LGBT + rights and other planks of the progressive agenda (although with the use of more politically correct tones and words in the 2010s). While these positions were often in line with the Vatican's own stances, the disagreements with this latter have not stopped (mainly because of their antithetic positions about immigration and the idea of a pluralist society), while a cleavage between different and scarcely compatible conceptions of militant Christianity has become more evident also at the civil society level.

\section{The Case of the Rassemblement National in France}

\section{Introduction}

The strict separation between the state and the Church, the principle of the laïcite (secularism) of the Republic enshrined in the first article of the Constitution, and the assertive secularism of state authorities (Kuru 2007, 571) may lead to assume that religious values have a limited role in the public sphere of contemporary France. However, the reinterpretations of the principle of the laïcite have opened the way to an accommodation of the place of religion in the French public sphere (Baubérot 2015) and Catholic values have continued to shape social and political behaviours, despite Catholicism as a metaphysical faith has shown declining appeal among French people (Le Bras and Todd 2013, 72). The mass public demonstrations against gay marriage in the streets of Paris in 2013 have also highlighted how Catholicism can still have an enduring capacity of mobilization in France (Béraud and Portier 2015). While past studies have acknowledged the influence of Catholicism on mainstream French right-wing parties (Haegel 2012; Rémond 2007), little focused debate has been devoted to exploring the interactions between religion and politics French right-wing populism.

\section{The Front National/Rassemblement National, Religion, and LGBT+ Issues}

Jean-Marie Le Pen established the FN in 1972 by aggregating several fringe radical right movements. In the 1980s, this new party was focused on immigration, security, and the promotion of neoliberal economic reforms. Although religion had a marginal role in the FN's political documents, Jean-Marie Le Pen was used to emphasize the importance of Catholic morality in his political action (Winock 2017, 1082-1085) and enrich his speeches with tropes taken from the Catholic repertoire (Alduy and Wahnich 2015, 57). The linkages between the FN and French Catholic traditionalist circles were promoted by Bernard Antony, a European deputy for the FN and one of the founders of the Committees Chrétien-Solidarité, an association that organized the pilgrimages to the cathedral of Chartres and the FN's marches for celebrating Jeanne d'Arc on 1st May. Despite the opinions expressed by Bernard Anthony and the Committees Chrétien-Solidarité were close to the positions of Msg. Lefebvre, the schismatic bishop who rejected the aggiornamento of Vatican II, they were not part of the Catholic dissent spearheaded by Lefebvre's movement (Durand 1996, 150). Bernard Antony, and Jean-Marie Le Pen alike, did not show much interest in the pastoral and theological

${ }^{14}$ Giornale, June 3, 2018. 
disputes that inspired Lefebvre's movement, and they only hijacked Catholic tropes to strengthen the FN's nationalistic message and attract the votes of conservative Catholic electors.

Despite the early FN did not elaborate any distinct religious politics, its family policies bore the imprint of Catholic moralism (Invaldi 2012, 104). In the book-manifesto issued in 1985, Jean-Marie Le Pen defined the family as the place for the transmission of genetic, cultural, and spiritual heritage (Le Pen 1985, 131), blamed 'the so-called feminist lobbies' for being responsible for the devaluation of the role of housewives (Le Pen 1985, 128), and criticized the evolution of moral values that led French governments to promote a kind of 'pro-cohabitation legislation' and support access to abortion (Le Pen 1985, 127-128).

A conflation of sexist nationalism (Crépon 2015) with Catholic moralism also characterized one of the few statements on LGBT+ issues made by Jean Marie Le Pen in the 1980s. During an interview released some weeks ahead of the 1984 European elections, the FN's President said that homosexuality was not a question to be debated, but only 'a biological and social anomaly' whose activities were a threat to civilization. ${ }^{15}$ According to Le Pen, homosexuality was a dangerous 'other', and the biological infertility of homosexual couples made them a threat to the survival of French civilization. However, as noted by the enquiries carried out by Nicolas Lebourg and Joseph Beauregard (2012), this firm rejection of homosexuality was accompanied by more tolerant attitudes toward homosexual militants, whose presence in the FN was well-known and accepted, ${ }^{16}$ as long as they did not politicize their sexual identity. This positioning thus led the FN to tolerate homosexual people but to strongly reject any extension of LGBT+ rights, like the bill on civil partnership (Pacte Civil de Solidarite - PACS) introduced in 1999, that the FN defined a law that imposed a 'deviant behaviour as a normative social model' (FN 2002, 42). Here, we can note some similarities between the FN's stances on LGBT+ questions and the positions of the Catholic Church that since Vatican II asked to accept homosexual people, but was against the legal recognition of homosexual unions, that the Congregation for the Doctrine of the Faith considered the approval of deviant behaviour (Congregation for the Doctrine of the Faith 2003, Conclusion). Notwithstanding the FN's claims on gender and LGBT+ questions shared several common aspects, French bishops were deeply distrustful toward Jean-Marie Le Pen and his party. Without mentioning it, in 1992, Msg. Duval, the President of the Bishops' Conference of France, wrote that Christians should not be seduced by a party that sustains certain Catholic values, but whose ideological roots are not consistent with the teaching of the Gospel. ${ }^{17}$

The FN's discourse on LGBT+ issues started to change in the early 2000s, and this evolution went hand-in-hand with a declining salience of Catholicism in the FN's official statements. The early 2000s were also characterized by the rise of Marine Le Pen, Jean-Marie's daughter, who intended to convey a more moderate image of the party. This strategy, popularly called de-demonization (dédiabolisation), implied a normalization of the FN's discourse that was evicted from some of its most radical claims. This development also implied a revision of the FN's positions on religion and LGBT+ issues. While in the 2002 presidential elections manifesto the PACS was defined as an example on the 'regressive social models' that will make French people disappear (FN 2002, 6), in an interview in December 2006, Jean-Marie Le Pen declared that 'I do not see much interest in this

\footnotetext{
15 Antenne 2, February 13, 1984.

16 'We [the FN] do not practice the fly policing.' (Jean-Marie Le Pen quoted in Le Point, 14 February, 2013).

17 www.la-croix.fr, 2020.
} 


\section{The Cases of the Lega and the Rassemblement National}

formula [PACS], but basically, if it allows some people to testify reciprocally their material interests,

I do not see any inconvenience'. ${ }^{18}$ However, the FN's founder had never completely left aside his homophobic attitudes, which he expressed in several public events.

The 'dédiabolisation' promoted by Marine Le Pen needed a change in the party leadership. This opportunity was provided by the national congress held in Tours in January 2011 in which the delegates were asked to choose the successor of Jean-Marie Le Pen. Two candidates contended for the party presidency: Bruno Gollnisch and Marine Le Pen. While Gollnisch, who was a long-lasting member of the FN and had close relationships with Catholic traditional circles (Delwit 2012, 33), did not intend to introduce any major change in the politics of the FN, Marine Le Pen, who was supported by the party apparatus and a generation of young militants, wanted to further the process of ‘dédiabolisation' of the FN. This latter position prevailed, and Marine Le Pen obtained a landslide victory against Gollnisch. ${ }^{19}$

Marine Le Pen impressed several ideological readjustments to the FN's ideology (Dezé 2017), also on religion, gender, and LGBT+ issues (Crépon 2015). She left out the references to Catholicism that characterized her father's speeches, to champion the secularism of the French Republic, that, according to her, was violated by some 'Muslim political-religious groups, which seek to impose religious laws at the expense of the laws of the Republic'. ${ }^{20}$ This 'falsified secularism' (Baubérot 2013), a misleading interpretation of it to stigmatize Muslim communities, was accompanied by the inclusion of homosexual persons among the people that the FN intended to defend. In a speech given in Lyon in 2010, Marine Le Pen declared:

I hear more and more testimonies about the fact that in some neighbourhoods it is not good to be a woman, neither homosexual, nor Jewish, nor even French nor white. ${ }^{21}$

The neighbourhoods Marine Le Pen was speaking about were those suburban areas, mostly inhabited by Muslim people, that she blamed for their allegedly sexist, homophobic, anti-Semitic, and racist attitudes. The new President of the FN thus abandoned the homophobic and religious rhetoric of her father only to support a nativist and anti-Muslim politics that relied on a biased interpretation of the principle of the laïcité. This ideological revision of the FN's stances on LGBT+ and religious issues was further emphasized by the decision of Marine Le Pen to appoint homosexual people in senior party positions and avoid to take part in the social protests against gay marriage in 2012-2013, organized by an umbrella organization called Manif pour Tous, which was principally composed of Catholic traditionalist groups (Béraud and Portier 2015).

Against this background, the FN's President was not well-placed to present herself as a reference for traditionalist Catholic organizations, whose positions were supported within the FN by Marion Maréchal-Le Pen, the niece of Marine Le Pen, a Catholic militant who acquired media visibility for her participation in the Parisian marches against gay marriage. However, Marion Maréchal-Le Pen did not promote any aggregation of conservative and traditional Catholic groups around the FN. Similarly to Jean-Marie Le Pen, she defended Catholic traditionalist positions on family, bioethical, and LGBT+ issues principally to build her public image as a Catholic-friendly politician and to

${ }^{18}$ Liberation, December 22, 2006.

${ }^{19}$ Le Figaro, January 16, 2011.

${ }^{20}$ L'Express, April 3, 2011.

${ }^{21}$ Marine Le Pen quoted in Le Figaro, December 11, 2010. 
strengthen a nationalist identity politics, not to uphold a distinct conception of Catholicism. In any case, her retirement from political life in May 2017 deprived the conservative Catholic wing of the FN of one of the most senior figures that could contest the leadership of Marine Le Pen and possibly become a magnet to attract the more intransigent groups of French Catholic traditionalism within the orbit of the FN.

The more tolerant attitude of Marine Le Pen toward homosexual persons did not imply a remarkable change of the party programmatic platform on gender issues and LGBT+ rights. A kind of political genderphobia (Henning 2018), and an ideologically-grounded defence of 'natural' gender roles continued to characterize the FN political positions. In March 2011, Sophie Robert, FN's regional counsellor in the region Rhone-Alpes, blamed the Lyon Gay Pride Parade for the supposedly Christianophobia of this event. ${ }^{22}$ Even though the 2017 presidential manifesto of Marine Le Pen did not contain the praise of the family 'based exclusively on the union of a man and a woman' included in the 2012 manifesto (FN 2012), it nonetheless showed a heteronormative imprint and stated Marine Le Pen's commitment to replace the gay marriage bill introduced in 2013 with an enhanced civil union (FN 2017, 12). During the electoral campaign, the FN's President also took the opportunity to remind her religiosity and her dissatisfaction with the Church for pushing forward a pro-migrant political agenda. ${ }^{23}$ However, these positions did not lead the FN's leader to engage in extensive criticisms against religious authorities or to present herself as a better defender of the Catholic values of the people.

The 2017 presidential elections were a big disappointment for Marine Le Pen who was significantly defeated in the second runoff by the centrist candidate Emmanuel Macron. ${ }^{24}$ Although Macron's permissive positions on gender, family, and bioethical issues alienated him the support of the Manif pour Tous, ${ }^{25}$ Marine Le Pen was not endorsed by this organization. A kind of mutual distrust divided the Manif pour Tous from the leader of the major French right-wing populist party. While the former was suspicious toward a possible political appropriation of its anti-gender campaign for electoral purposes, the latter did not show any sign to leave aside the apparent secularism and the effort to modernize the public image of her party, which were core elements of the 'dédiabolisation' of the FN that Marine Le Pen had pursued since the early 2000s.

The change of the name of the FN in Rassemblement National (RN) in June 2019 was not followed by a revision of this party's stance on religion and LGBT+ issues, which continued to be affected by some degree of ambiguity, namely the defence of moral conservative positions bearing the imprint of Catholicism, but a refusal to become the political reference of Catholic traditionalist organizations. This ambiguous political strategy was also shown during the debate on the revision of the bioethical law in 2019-2020, when the RN's deputies contrasted new permissive measures proposed by Macron administration, notably the legalization of assisted reproductive technologies for single women and lesbian couples but most of them refused to demonstrate against these policies along with traditionalist Catholic organizations. The ongoing radicalization of several fringe Catholic organizations, following the controversies over gay marriage (Raison du Cleuziou 2019) may propel a reconfiguration of the relations between religion and politics in France, and possibly a repositioning

\footnotetext{
${ }^{22}$ Quoted in Égalité LGBT, 2012.

${ }^{23}$ La Croix, April 14, 2017.

${ }^{24}$ Le Monde, May 7, 2017.

${ }^{25}$ Le Point, April 26, 2017.
} 


\section{The Cases of the Lega and the Rassemblement National}

of the $\mathrm{RN}$ on religious issues. However, the political history, ideological background, and party leadership, which we have considered in the previous sections, make unlikely that the RN would become part of the French Catholic dissent or provide a political representation of its demands.

\section{Concluding Remarks}

This paper has shed light on the role of religion in the development of the political positions and discourses of the LN/Lega and FN/RN on LGBT+ rights from their foundation to the present day. These two parties have shared two key features relevant for this paper: strong ties with the conservative wing of the Catholic world; and the attitude to defend the legacy of a patriarchal worldview. In the last decade, both of them have undergone a renewal of their political images brought about by young leaders against the will of the parties 'founding fathers'. In the case of the $\mathrm{LN}$, this has mainly implied the rejection of the old regionalist and anti-southern perspective to become a fully-fledged nationalist party (Biorcio 2015); while for the FN/RN, this process has meant the pursuit of a strategy of 'dédiabolisation' with the abandonment of the most radical positions and anti-Semitic stances (Camus and Lebourg 2015). Although neither the Lega nor the RN have become advocates of marriage equality, they have both partly softened their positions on LGBT + issues, at least in terms of tones and language, if not of policies. This process is more evident for the $\mathrm{RN}$, in which outspoken homosexuals have held senior party positions, while for the Lega LGBT+ issues are still seen with considerable hostility (also considering its strong reliance on the 'gender ideology' thesis and the party's relations with national and international conservative Christian organizations marked by very hostile stances towards the LGBT+ community).

Religion, notably a civilizational interpretation of Catholicism, focused on identity rather than belief and practices, has played a decisive role in shaping the development of the positions of the LN/Lega and FN/RN on LGBT+ issues. However, since in recent years both parties have partly mitigated their tones towards homosexual people mainly in the context of their anti-Islamic and anti-immigrant platforms, they are today affected by some degree of dyscrasia. Although their official discourses especially the RN's ones - have partly been purged from patriarchal and politically incorrect overtones, their political proposals and the popular base of militants are - especially in the case of the Lega - still marked by conservative and 'traditional' views on genders and the family roles.

In any case, our historical analysis let us conclude that the positions of the LN/Lega and FN/RN do not seem to be primarily a phenomenon of religious dissent, although in the early phases of both parties their opposition to post-conciliary Catholicism expressed in the appreciation for Msg. Lefebvre ultra-conservative vision of Christianity. In the case of the LN, moreover, the adoption of neo-Pagan rituals and symbols was the manifestation of a political project aiming at creating a distinct northern Italian identity, also in religious terms. In this context, anti-clerical feelings even found a place, with the identification of the Catholic hierarchies as part of the "elite" opposed to the "pure people", in the context of the party's populist worldview.

In the twenty-first century, this situation has significantly evolved, particularly after the leadership changes that both parties have experienced in the early 2010s. This is particularly true in the French case as the RN has left aside the Catholic rhetoric that characterized Jean-Marie Le Pen's speeches (Alduy and Wahnich 2015) to present itself as a defender, if not the better defender, of the laïcité of the French Republic. The situation is more complex in the case of the Lega. On the one hand, the party's adoption of religious language and symbols and its defence of traditionalist positions on some religion and morality-related issues does not seem to be motivated by religious, but only by identitydriven and strategic concerns. On the other hand, the choice to harshly criticize the Vatican on 
immigration- and multiculturalism-related issues has aligned with the positions of some ultraconservative Catholics who are not at ease with Pope Francis's management of the Church (and, more broadly, with post-conciliary Catholicism). This has undoubtedly catered on strains and polarization probably already existing within the Italian Catholic community, and exasperated them (Ozzano, 2019, 2016). As a consequence, this orientation has put the party - at least in some fields in a position of competition with the Church hierarchies in defining what it means to be an engaged Christian in today's Italy. This is particularly true in the most recent phases, with Salvini's use of devotional language and symbols during his political rallies since the campaign for the 2018 elections, marking an upgrading of the religious rhetoric of the party which might turn, in the coming years, into a fully-fledged phenomenon of religious dissent.

\section{References}

Akkerman, Tjitske, Sarah L. de Lange, and Matthijs Rooduijn. eds. 2016. Radical Right-wing Populist Parties in Western Europe: Into the Mainstream? London: Routledge.

Alduy, Cécile and Wahnich, Stéphan. 2015. Marine Le Pen Prise aux Mots. Décryptage du Nouveau Discours Frontiste. Paris: Seuil.

Arato, Andrew, and Jean L. Cohen. 2017. “Civil Society, Populism and Religion.” Constellations, 24 (3): 283-95. https://doi.org/10.1111/1467-8675.12312.

Baubérot, Jean. 2014. La Laïcité Falsifiée. Paris: La Découverte. . 2015. Les Sept Laïcités Françaises. Paris: Éditions de la Maison des Sciences de l'Homme.

Béraud, Céline and Portier, Philippe. 2015. Métamorphoses Catholiques: Acteurs, Enjeux et Mobilisations depuis le Mariage pour Tous. Paris: Éditions de la Maison des Sciences de l'Homme.

Brubaker, Rogers. 2017. "Between Nationalism and Civilizationism: The European Populist Moment in Comparative Perspective.” Ethnic and Racial Studies 40 (8): 1191-226. http://dx.doi.org/10.1080/01419870.2017.1294700

Camus, Jean-Yves and Nicolas Lebourg. 2015. Les Droites Extrêmes en Europe. Paris: Seuil.

Congregation for the Doctrine of the Faith. 2003. Considerations Regarding Proposals to Give Legal Recognition to Unions between Homosexual Persons. http://www.vatican.va/roman_curia/congregations/cfaith/documents/ rc_con_cfaith_doc_19861001_homosexual-persons_en.html [Accessed 10 May 2020].

Crépon, Sylvain. 2015. 'La Politique des Mœurs au Front National.' In Les Faux-semblants du Front National, edited by Sylvain Crépon, André Dézé, and Nonna Mayer, 185-205. Paris: Presses de la Fondation Nationale des Sciences Politiques.

Delwit, Pascal. 2012. "Les Étapes du Front National ‘1972-2011.". In Le Front National: Mutations de l'Extrême Droite Française, edited by Pascal Delwit, 12-36. Bruxelles: Éditiones de l'Université de Bruxelles.

DeHanas, Daniel N. and Marat Shterin. 2018. "Religion and the Rise of Populism." Religion, State \& Society, 46 (3): 177-85. https://doi org/10.1080/09637494.2018.1502911.

De Lange, Sarah L. and Mügge, Liza M. 2015. "Gender and Right-wing Populism in the Low Countries: Ideological Variations across Parties and Time." Patterns of Prejudice 49 (1-2): 61-80. https://doi.org/ 10.1080/0031322X.2015.1014199.

Dezé, Alexandre. 2017. Comprendre le Front National. Levallois-Perret: Bréal.

Diotallevi, Luca. 2002. "Internal Competition in a National Religious Monopoly: The Catholic Effect and the Italian Case." Sociology of Religion 63 (2): 137-55. https://doi.org/10.2307/3712562.

Durand, Géraud. 1996. Enquête au Cœur du Front National. Paris: Grancher.

Francis. 2020. Encyclical Letter Fratelli Tutti. http://www.vatican.va/content/francesco/en/ encyclicals/ documents/papa-francesco_20201003_enciclica-fratelli-tutti.html. [Accessed 23 October 2020].

Front National. 2002. Pour un Avenir Français. Le Programme de Gouvernment du Front National. Paris: Godefroy de Bouillon.

- 2012. Notre Project. Programme Politique du Front National. Available at: http://www.frontnational. com/pdf/projet_mlp2012.pdf [Accessed 10 November 2018].

- 2017. 144 Engagements Présidentiels. Available at: https://www.marine2017.fr/wp-content/uploads/ 2017/02/projet-presidentiel-marine-le-pen.pdf [Accessed 09 March 2019]. 


\section{The Cases of the Lega and the Rassemblement National}

Garbagnoli, Sara. 2017. 'Italy as a Lighthouse: Anti-Gender Protests between the 'Anthropological Question' and National Identity.” In Anti-Gender Campaigns in Europe: Mobilizing Against Equality, edited by Roman Kuhar and David Paternotte, 151-73. London: New York: Rowman \& Littlefield International.

Garbagnoli, Sara and Massimo Prearo. 2017. La Croisade «anti-Genre». Du Vatican Aux Manifs Pour Tous. Paris: Textuel.

Garelli, Franco, Gustavo Guizzardi and Enzo Pace, eds. 2003. Un Singolare Pluralismo. Indagine Sul Pluralismo Morale e Religioso Degli Italiani. Bologna: Il Mulino.

Guolo, Renzo. 2011. Chi Impugna La Croce. Lega e Chiesa. Roma/Bari: Laterza.

- 2019. "La Chiesa di Papa Francesco e la Lega non Possono che Essere Nemici." Espresso, February 08.

Kuhar, Roman and David Paternotte, eds. 2017. Anti-Gender Campaigns in Europe: Mobilizing Against Equality. London: Rowman \& Littlefield International.

Kuru, Ahmet T. 2007. "Passive and Assertive Secularism: Historical Conditions, Ideological Struggles, and State Policies toward Religion.” World Politics, 59(4): 568-94. https://doi.org/10.1353/wp.2008.0005.

Haegel, Florence. 2012. Les Droites en Fusion: Transformations de l'UMP. Paris: Presses de la FondationNationale des Sciences Politiques.

Haynes, Jeffrey. 2019. "From Huntington to Trump: Twenty-Five Years of the 'Clash of Civilizations.” The Review of Faith \& International Affairs 17 (1): 11-23. https://doi.org/10.1080/15570274.2019.1570755.

Hennig, Anja. 2018. "Political Genderphobia in Europe: Accounting for Right-wing Political-Religious Alliances against Gender-sensitive Education Reforms since 2012." Zeitschriftfür Religion, Gesellschaft und Politik 2: 193-219.https://doi.org/10.1007/s41682-018-0026-x.

Ignazi, Piero. 2006. Extreme Right Parties in Western Europe. Oxford: Oxford University Press.

. 2012. "Le Front National et les Autres. Influence et Évolutions." In Le Front National: Mutations de l' Extrême Droite Française, edited by Pascal Delwit, 37-55. Bruxelles: Éditiones de l'Université de Bruxelles.

Invaldi, Gilles. 2012 "Permanences et Évolutions de l'Idéologie Frontiste." In Le Front National: Mutations de l'Extrême Droite Française, edited by Pascal Delwit, 95-112. Bruxelles: Éditiones de l'Université de Bruxelles.

Lebourg, Nicolas, and Joseph Beauregard. 2012. Dans l'Ombre des Le Pen: une Histoire des Numéros 2 du FN. Paris: Nouveau Monde.

Le Bras, Hervé and Emmanuel Todd. 2013. Le Mystère Français. Paris: Seuil.

Le Pen, Jean-Marie. 1985. Pour La France. Programme du Front National. Paris: Albatros. . 1995. Le Contrat pour la France avec les Français. Paris: Albatros.

Marzouki, Nadia and Duncan McDonnell. 2016. "Populism and Religion.” In Saving the People. How Populists Hijack Religion, edited by Nadia Marzouki, Duncan McDonnell, and Olivier Roy, 1-11. London: Hurst \& Co.

McDonnell, Duncan. 2016. “The Lega Nord. The New Saviour of Northern Italy.” In Saving the People. How Populists Hijack Religion, edited by Nadia Marzouki, Duncan McDonnell and Olivier Roy, 12-28. London: Hurst \& Co.

Moscati, Maria Federica. 2010. "Trajectory of Reform: Catholicism, the State and the Civil Society in the Developments of LGBT Rights.” Liverpool Law Review 31 (1): 51-68. https://doi.org/10.1007/s10991-0109072-y.

Mudde, Cas. 2016. “The Study of Populist Radical Right Parties: Towards a Fourth Wave.” Working Paper Series, no. 1, University of Oslo: Center for Research on Extremism: The Extreme Right, Hate Crime and Political Violence (C-REX).

Mudde, Cas and Cristóbal Rovira Kaltwasser. 2015. "VoxPopuli or Vox Masculini? Populism and Gender in Northern Europe and South America." Patterns of Prejudice 49 (1-2): 16-36. https://doi.org/10.1080/0031322X.2015.1014197.

Müeller, Jan-Werner. 2016. What is Populism? Philadelphia: University of Pennsylvania Press.

Occhetta, Francesco. 2018. “Alla Vigilia delle Elezioni Politiche in Italia." La Civiltá Cattolica, 4023 (3): $238-45$.

Oggiano, Francesco. 2018. "Fontana, il ministro per la Famiglia contro aborto e coppie gay." VanityFair.it (blog). June 01, 2018. https://www.vanityfair.it/news/politica/2018/06/01/lorenzo-fontana-ministro-famiglia-gayaborto-gender.

Ozzano, Luca. 2015. "The Debate about Same-Sex Marriages/Civil Unions in Italy's 2006 and 2013 Electoral Campaigns." Contemporary Italian Politics 7 (2): 144-60. https://doi.org/10.1080/23248823.2015.1041250.

- 2016. "Two Forms of Catholicism in Twenty-First-Century Italian Public Debate: An Analysis of Positions on Same-Sex Marriage and Muslim Dress Codes." Journal of Modern Italian Studies 21 (3): 464-84. https://doi.org/10.1080/1354571X.2016.1169888. 
. 2019. "Religion, Cleavages, and Right-Wing Populist Parties: The Italian Case." The Review of Faith \& International Affairs 17 (1): 65-77. https://doi.org/10.1080/15570274.2019.1570761.

_ 2020. "Last but Not Least: How Italy Finally Legalized Same-Sex Unions." Contemporary Italian Politics 12 (1): 43-61. https://doi.org/10.1080/23248823.2020.1715594.

Ozzano, Luca, and Alberta Giorgi. 2016. European Culture Wars and the Italian Case: Which Side Are You On? London: Routledge.

Passarelli, Gianluca and Dario Tuorto. 2018. La Lega di Salvini. Estrema Destra di Governo. Bologna: Il Mulino.

Prearo, Massimo. 2017. "Le Cadrage Religieux de la Mobilisation «Anti-genre » : Une Étude Micro-événementielle du Family Day.” Genre, sexualité \& société, no. 18 (December). https://doi.org/10.4000/gss.4100.

Raison du Cleuziou, Yann. 2019. Une Contre-Révolution Catholique: Aux Origines de La Manif pour Tous. Paris: Seuil,

Rémond, René. 2007. Les Droites Aujourd'hui. Paris: Seuil.

Rossi Barilli, Giovanni. 1999. Il Movimento Gay in Italia. Milano: Feltrinelli.

Rydgren, Jens. ed. 2018. The Oxford Handbook of the Radical Right. Oxford: Oxford University Press.

Scrinzi, Francesca. 2017. “A 'New' National Front? Gender, Religion, Secularism and the French Populist Radical Right.”. In Gender and Far Right Politics in Europe, edited by Köttig Michaela, Bitzan Renate, and Petö, Andrea, 127-40. London: Palgrave-Macmillam.

Stavrakakis, Yannis. 2004. “Antinomies of Formalism: Laclau's Theory of Populism and the Lesson from Religious Populism in Greece.” Journal of Political Ideologies 9 (3): 253-67. https://doi.org/10.1080/ 1356931042000263519.

Vaggione, Juan Marco. 2005. "Reactive Politicization and Religious Dissidence. The Political Mutations of the Religious.” Religion and Politics 31(2): 233-55. https://doi.org/10.5840/soctheorpract200531210.

Verloo, Mieke. 2018. "Gender Knowledge, and Opposition to the Feminist Project: Extreme-Right Populist Parties in the Netherlands." Politics and Governance 6: 20-30. http://dx.doi.org/10.17645/pag.v6i3.1456.

Winock, Michel. 2017. La France Républicaine: Histoire Politique XIXe-XXIe Siècle. Paris: Laffont. 